\title{
Dialogue on Reform in Mainstream Economics and its Implications for the Islamic Economics Discipline
}

\author{
Jack Reardon \\ Founding Editor, International Journal of Pluralism and Economics Education \\ Professor, University of Wisconsin-Eau Claire, USA
}

\begin{abstract}
While the most recent financial crisis highlighted a myriad of problems within mainstream economics, the call for reform has been widespread, long-standing, and deep-seated. This paper reaffirms this call from an historical perspective, with accelerating climate change adding a sense of urgency. Unfortunately, mainstream economics is not capable of self-reformation; instead, it has erected formidable barriers. Not surprisingly, as this paper highlights, little substantive reform has occurred within mainstream economics, while the outside urge to reform continues unabated. This paper calls for pluralism as a compelling and necessary (but not sufficient) intellectual foundation for reform, and concludes by logically pointing to the wisdom of Islamic economics.
\end{abstract}

Keywords: Pluralism, Economics education, Reform of economics, Pluralism.

JEL Classification: A1, A2, B2, Y8

KAUJIE Classification: G0, G1, G6, G63 


\section{Introduction: How Relevant is the Economics Profession to Pressing Real World Problems?}

Before answering this question, two clarifying points must be made. First, the economics profession is not monolithic; it does not speak with one voice. Deep chasms exist within economics, splintering it into separate "tribes [each with] a specific culture and specific habits, norms and rules" (Weehuizen, 2007, p. 165). The tribes do not share the same beliefs or objectives, nor even the same history. Instead of economics, we have institutional, green, classical, Islamic, Austrian, Marxist, post-Keynesian, feminist, Sraffian, and neoclassical economics. The public suffers. But the problems of our generation are not institutional, green, classical, etc.; nor are they economic. They are complex and multi-dimensional, deserving the active attention and full cooperation of all economists. It is beyond the scope of this paper to investigate the relevance of each 'tribe' to solving realworld problems; instead, given this paper's objective, I will focus on only one tribe: neoclassical economics.

This leads us to the second point. Since what is accepted as mainstream economics changes over time, and is somewhat subjective, I will discuss neoclassical economics, which despite changing a little around the edges, has long retained its core beliefs of individualism, optimization, and equilibrium. Neoclassical economics uses a $19^{\text {th }}$ century, linear, mechanistic lens to construct its economy: a stand-alone, abstract system that emerges naturally from the actions of individual agents (Earle, Moran, \& WardPerkins, 2016, p. 39). Like all of the economic tribes, neoclassical economics involves certain assumptions about the economy: how to define it, what to focus on, how humans behave within it, and the appropriate research methods (Earle et al., 2016, p. 37). This would be palatable (and even welcomed) if it was offered in the spirit of pluralism, engaging in active debate with the other tribes. However, it is rammed down student's throats as if it is the only view; as if the other tribes did not exist. In a rapidly changing world in which we need the active cooperation of all social scientists, this is a problem.

Alfred Marshall, in the preface to the eighth edition of his Principles of Economics, wrote that "economic conditions are constantly changing, and each generation looks at its own problems in its own way"
(Marshall, 1890/1946, p. v). Our economic conditions are indeed rapidly changing, spurred by climate change which, unless immediate corrective actions are undertaken now, will cause irreversible damage; and by technology which is blurring the distinction between consumer and producer, markets and commons. The new technology is decreasing the marginal cost of producing many products, potentially leading to abundance rather than presumed scarcity, while changing the conception of work, employment and unemployment, and how labor is compensated. 3-D printing, which is just taking off now, will radically change the nature of the firm and the industry structure. Big data and the Internet of Things are a cause of concern now, especially regarding privacy and monopolization, but could very well provide solutions, particularly in producing renewable energy and distributing it at low marginal cost.

This is our new world; a world that students are concerned about and apprehensive. A world that needs a new lens and a new vision. But neoclassical economics is silent on how our world is changing, insisting on teaching the same outdated theories and concepts (some of which, as I will discuss shortly, have caused our current predicament), as if the new economic conditions did not exist. It is a tragedy (and a crime) that today's students,

are receiving much the same instruction about how firms set prices as did their counterparts at the end of the $19^{\text {th }}$ century... Think of the many revolutions in our understanding of the physical world which have occurred in the $20^{\text {th }}$ century from Newtonian to Einsteinian physics; from Mendelian genetics to DNA and the human genome; from determinism to chaos theory. Any scientist from the $19^{\text {th }}$ century would be bewildered by what is commonplace today in his [sic] discipline - save an economist. (Keen, 2011, pp. 168-169)

Indeed, it is not surprising that "economics as currently constituted and practiced, acts as a most effective barrier against the understanding of [our] problems, owing to... its timorous refusal to look into the real nature of things" (Schumacher, 1973/ 1989 , p. 50). This is a very serious indictment seconded by Keen: "neoclassical economics, far from being the font of economic wisdom, is actually the biggest impediment to understanding how the economy actually works" (Keen, 2011, p. 15). 
Our profession needs big thinkers, people like Smith, Marx, and Keynes, who think in terms of the big picture, who ponder and investigate how economic systems work (Backhouse \& Bateman, 2011). Instead, we are producing ideological technicians, overly preoccupied with minutiae, largely unaware of the new economy, and ignorant of the need for reform.

Part of the problem, is of course, the incestuous relationship between neoclassical economics and capitalism, which has rarely been at scientific arm's length (Dowd, 2004, p. xiii). Fred Lee superbly documented the history of this relationship, writing: "...fused together in neoclassical economics by 1900 was a research agenda to objectively explain how capitalism worked with the ideological agenda that promoted capitalism... [which] ensured that neoclassical economics was disposed to be anti-pluralistic" (Lee, 2009, pp. 26-27).

Capitalism has long been praised for its ability to produce unprecedented wealth. Marx and Engels, two of capitalism's fiercest critics, wrote, "The bourgeoisie, during its rule of scarce one hundred years, has created more massive and more colossal productive forces than have all the preceding generations together" (Marx \& Engels, 1848/1992, pp. 7-8). At the same time, this ability to produce immense wealth has also produced intense poverty, often side-by-side, as Henry George noted more than a century ago:

\begin{abstract}
discovery upon discovery, and invention after invention, have neither lessened the toil of those who most need respite, nor brought plenty to the poor...widespread destitution is found in the midst of the greatest abundance...it may clearly be seen that material progress does not merely fail to relieve poverty - it actually produces it. (George, 1879/1935, pp. 5, 7, \& 9)
\end{abstract}

I blame neoclassical economics and its economics education for the inability to see our rapidly changing economy. For its inability to offer $21^{\text {st }}$ century solutions for our $21^{\text {st }}$ century problems. For its inability to produce big thinkers. For the failure to reconceptualize capitalism so that it produces wealth while minimizing poverty and inequality, and for its failure to devise effective solutions for climate change. I have made it my life's work to change how we educate our economists. To paraphrase Charles Snow, "There is no excuse for letting another generation be as vastly ignorant" (1988, p. 61). Hopefully, this discussion paper will contribute to this much-needed task.

\section{Is There A Need for Reform of Economics?}

In the middle of the most recent financial crisis Edward Fullbrook noted that "if universities continued to use for nuclear engineering a textbook by an engineer who had headed a team managing a nuclear power plant that without external causes exploded creating a huge devastation, there would be a public outcry" (Fullbrook, 2009, p. 22). Indeed. Or imagine the outbreak of a disease, an epidemic, that caught the medical profession unaware, with most of the profession (and textbooks) fastidiously denying the epidemic's possibility? Certainly, an enraged public would demand radical change.

But that is not the case with economics. The public has not become enraged, partly due to a disconnect between what the public perceives as the economy and what economists do and how it affects them. Economists have become elitist, aloof, and disconnected from the public (Earle et al., 2016). Nevertheless, there has been a steady call for fundamental reform. Consider the recent books criticizing the profession, demanding radical change ranging from A Guide to What's Wrong with Economics (Fullbrook, 2004), to The Econocracy: The Perils of Leaving Economics to the Experts (Earle et al., 2016) and half a dozen books in between (for an expanded discussion, see Reardon, Madi, \& Cato, 2018, p. 13, note \#6).

While the inability of the economics profession to predict the crisis intensified the call for reform, it predates the crisis. In 1969, Hugo Radice, as just one example, a Cambridge University postgraduate student in economics posted a flyer ${ }^{(1)}$,

Many of us who study or teach economics feel that much of our subject matter is irrelevant and meaningless in the face of the intense social and economic problems of the world. For the most part, economics takes the existing capitalist system for

(1) This flyer, as Lee notes, led to a London Conference in January 1970 which developed the Conference of Socialist Economics, an important institution in developing heterodox economics in the UK; and then led to the Bulletin of the Conference of Socialist Economists which in 1976 was superseded by the journal Capital and Class (Lee 2009, pp. 127$130)$. 
granted, and is concerned solely with making it work more efficiently, or with making marginal adjustments which are totally inadequate. Furthermore, economists persistently deny that economic problems are inevitably social and political problems as well. (quoted in Lee, 2009, p. 127)

And more than thirty years later, French economics students posted a similar demand:

Out of all the approaches to economic questions that exist, generally only one is presented to us...We do not accept this dogmatism. We want a pluralism of approaches, adapted to the complexity of the objects and to the uncertainty surrounding most of the big questions in economics. (PostAutistic Economics Network, 2000).

In fact, the demand for reform can be traced back to the development of institutional economics in the late $19^{\text {th }}$ century, and to the broader development of heterodox economics during the 1930s. Neoclassical economics has simultaneously parried any claims for reform while bullying its critics (Lee, 2009). This is a serious problem, which contravenes intellectual freedom and actively distorts how we perceive the economy.

To commemorate the $500^{\text {th }}$ year anniversary of the start of the Catholic Reformation, I published 95 theses (i.e., debating points) calling for immediate reform of the economics profession (Reardon, 2017b). Without it, neoclassical economics offers students, the public, and policy makers a $19^{\text {th }}$ century map for studying $21^{\text {st }}$ century problems, which is worse than no map at all,

The problems of our generation are formidable ranging from climate change to increasing inequality. The public needs an effective, crisis-free, fully-functionally economics to tackle our problems. We demand a reconceptualized economics that looks to the future for inspiration; an economics that includes rather than excludes, that denies there is only one truth, that encourages and welcomes diversity (Reardon, 2017b, p. 319).

\section{Is Pluralism the Answer?}

In her influential book, The Soulful Science (2007), Diane Coyle boasts of the progress that (neoclassical) economics has made in moving beyond the constricting assumptions of rational agents, perfect competition, etc. And she also invidiously distinguishes economists from non-economists not by subject, but by research method:
The combination of rational maximizers and the equilibrium concept, in theories tested against a counterfactual and refined by comparison with the data, makes economics incredibly powerful. For all that its practitioners criticize us, the other social sciences don't have anything remotely approaching the flexibility and strength of the economic method, nor the capacity of economic models to be honed and tested empirically...That's why Paul Ormerod, for all his sharp criticisms of the mainstream, is an economist but John Kenneth Galbraith wasn't. (Coyle, 2007, pp. 252-253)

And, according to her litmus test, neither would be Adam Smith, Alfred Marshall, or Karl Marx, never mind most heterodox economists.

This invidious distinction between us and them, between what constitutes 'good economics' and 'bad economics', without attempting to understand the other research agendas or methodologies (nor realizing that other tribes within economics, and many social sciences, developed precisely because of what neoclassical economics ignored) is, at least for me, a major rationale for pluralism. Instead of unfairly judging, we should welcome and embrace those who differ from us; and although, we need not agree, we can at least understand, empathize, and dialogue.

As founding editor of the International Journal of Pluralism and Economics Education (IJPEE), and the author of The Handbook of Pluralist Economics Education (2009), I have written extensively on pluralism and heartily endorse and accept it (for an expanded discussion on the origin of pluralism, its importance, and its many usages, see: Negru, 2009; Negru, 2010; and Heise, 2017). Three things I have learned about pluralism that are relevant for this paper. One, pluralism, like democracy, freedom, and sustainability, is a complex, multifaceted word, existing on several levels: ontology (understanding of reality); epistemology (theory of knowledge); methodological (the practice of economics); theoretical (different theories within economics); and pedagogical (how we teach economics) (Dow, 2009, p. 45). So, in discussing pluralism, it is important to specify which level. Two, for such an important word (and maybe because of it), a commonly accepted definetion remains elusive - perhaps this will change as the 
term gains currency ${ }^{(2)}$. For me, a simple, yet illustrative definition is: listening, engaging, and welcoming different (often opposing) views.

For a person to be pluralist means that he/she is humble about what we don't know, realizes that the world is governed by uncertainty, and understands that there are different understandings of reality. Given these different visions, and that no vision can be proved correct, there is a need for pluralism. This doesn't mean that there aren't right or wrong answers, or that we must always agree, only that given different visions of reality, we must listen, dialogue, and engage with others. Pluralism does not mean that anything goes, nor that all views are legitimate, although,

we must guard against an arbiter (or faction) deciding what is and what is not legitimate. The arbiter/faction might squash and extirpate the new, the untried, the radically different. We need all views. This is a problem with today's economics and the main reason for its chasm: dissenting views are delegitimatised... new views are shunted before they are broached (Reardon, 2017b, p. 323).

The antithesis of pluralism is monism, which stubbornly insists that there is only one reality, one way of doing things, without any need to listen to opposing views, no need to dialogue. But "monism, by filtering out different views, prevents one from knowing which view is better in which situations... [it] constrains and disables" (Reardon, 2009, p. 267).

The third item that I have learned about pluralism is that it is a modus operandi, a state of mind, so that in addition of being cognizant of different views, a pluralist actively engages with different views, and actively engages, especially those with opposing views. So, in pedagogical pluralism, for example, it is equally important to consider what is taught, as to how it is taught. Are students forced to think only one way (regardless of whether it is mainstream or heterodox), or are students taught how to think pluralistically and how to open up their minds. The former is proselytization, the latter is education.

(2) See the IJPEE's 'Roundtable on Pluralism' (Reardon, 2015) for an exploration of varied definitions of pluralism, along with its use in contemporary economics. Also see the critique by Negru and Negru (2017).
It is very difficult to develop a pluralist modus operandi, which explains why pluralism cannot be implemented overnight. Nevertheless, all recent movements to reform economics have called for pluralism. In 2014, for example, the student-led organization, Rethinking Economics, posted:

\begin{abstract}
We need to recognize the plurality within economics. In most courses "economics" is shorthand for "neoclassical economics". There is no recognition of the variety of schools of thought within economics, across history or across the world. Academic integrity requires that alternative economic theories be introduced to students, alongside those currently taught (Rethinking Economics, 2014).
\end{abstract}

If a reconceptualized economics is to help solve our generation's problems, it must become pluralist. Nevertheless, although this is necessary, it is not sufficient:

Pluralism, both its ethos and epistemology, is extremely important, but no matter how robust it may become among economists it will never be a sufficient basis for breaking the hegemony of neoclassical economics. That will require a new cohesion of underlying economic ideas other than the neoclassical ones and which heterodox schools will in the main accept and, even more importantly, which their members will become in the practice of relating to their particular school of thought as they currently do with neoclassical ideas. (Fullbrook, 2010, p. 101).

But even if economics was completely pluralist (if so, how would we recognize it?), we would need to distinguish economics from non-economics and delineate the borders of our discipline. Who will do this? How would they get to decide? What will be the criteria? How will the criteria change over time? And what about new theories, or new visions of reality? Will they be accepted on an even footing?

\section{How Far and Genuine Have Been the Calls for Reform?}

The call for systematic reform is part and parcel of the development of heterodox economics, and in this sense, the calls for reform have been long-standing, visceral, and genuine. But due to fundamental problems in neoclassical economics education (proselytization is more accurate), neoclassical economists are prevented from recognizing that there is a problem, never mind becoming equipped with the necessary resources to change. 
In light of this, Fred Lee argued that heterodox economics should develop its own robust research platform, reaching out to students, developing networks with other heterodox economists, while challenging the invidious benchmarking and journal ranking (Lee, 2009, p. 206). While I agree this is all well and good, it is even more critical to radically change (neoclassical) economics education.

It should not be surprising that within neoclassical economics the calls for reform have been tepid at best, and any reforms have been more superficial: tinkering around the edges, improving the packaging. Edward Fullbrook noted that "the generals of [the] mainstream status quo, along with middle ranks, show no signs of giving ground or even of feeling the need for appeasement" (Fullbrook, 2010, p. 94). And the crisis "doesn't seem to have any decisive impact on the way economics is taught" (Otsch \& Kapeller, 2010 , p. 22). The emphasis is overwhelmingly on a re-packaged 'more of the same'. Witness the remarks made by N. Gregory Mankiw, during the midst of the most recent financial crisis: "Students still need to learn about the gains from trade, supply and demand, the efficiency properties of market outcomes, and so on. These topics will remain the bread-and-butter of introductory courses" (Mankiw, 2009).

Insisting on teaching the same stuff, underscores the profession's inability to self-reform. In fact, three reasons can be given for this failure. One, neoclassical economics education does not enable its economists to ask such a question, nor does it equip them with the necessary resources to effectuate workable solutions. Two, human nature constricts admitting need for reform, especially when tantamount to admitting that one's life work has been a waste - typical in all intellectual disciplines. Such resistance is "not a violation of scientific standards but an index to the nature of scientific research itself' (Kuhn, 1962/2012, p. 150). This is why Kuhn $(1962 / 2012$, p. 150) notes that acceptance of new theory must sometimes wait until the passing of the older generation. But we don't have the luxury of waiting another generation: economics education must be reformed now. And third, even if neoclassical economics is well equipped to reform, it is in its best interest not to. In the late $19^{\text {th }}$ century, neoclassical economics developed as a theory of prices - more so, how relative prices change rather than how they are determined. The efficacy of such a theory is a function of scarcity: if goods are free, abundant, or can be produced with a declining marginal cost, then a theory of relative prices, determined by scarcity has no meaning.

\section{How Useful Have Been the Reforms?}

While much work has been done to devise a reconceptualized economics and to describe what it will look like, while offering pluralist recipes for interested teachers, departments, and universities; the important work of mapping these formidable obstacles in minute detail has not received adequate attention. This is important since the type of reformed economics implemented will depend upon how these obstacles are surmounted.

Edward Fullbrook noted that the basic institutions of neoclassical economics: university departments, associations, journals, classification systems, economics 101 textbooks, and its basic narrative, collectively and interactively block any effort at meaningful reform. And that "this intransigence and insuperability stems from the fact that as institutions, although independently constituted, they are interlocking and their characteristics inter-determined" (Fullbrook 2010, p. 95). Unfortunately, nine years later, this interconnected nexus is still going strong. The public suffers, and the beat goes on.

Thus, it should be no surprise that effective and meaningful reform has either been parried or rechanneled into something far less meaningful. A good example, of course, is the CORE, which despite its ostensibly good intentions, adamantly insists that only one perspective is valid, while not encouraging students to question/challenge neoclassical economics (Earle et al., 2017, pp. 112-113),

it remains the case that a narrow, fixed body of knowledge is handed down from one generation to the next, leaving little room for debate. The pedagogy is flawed because it fails to prepare students for living and working in a complex, diverse world in which knowledge is fluid, uncertain and contested. . The CORE curriculum shows that the rejection of other approaches is deeply embedded in the discipline. (Earle et al., 2017, p. 115).

The failure of the CORE underscores the difficulty in implementing true reform, and how easy it is for the vested interests to usurp and then control the process, ostensibly speaking for all, but in reality, only benefitting the few. 
Thankfully, more real-world (and pluralist) textbooks are being written, and students are more receptive; yet, neoclassical textbooks retain their stronghold. Consider Mankiw's Principles of Economics, which Fullbrook used in 2009 (the $4^{\text {th }}$ ed., and the "dominant basic text internationally") to demonstrate "how both the economics profession and the public which it educates became so ignorant, misinformed, and unobservant of how economies work in the real world" (Fullbrook, 2009, p. 17). If real, substantive reform occurred in economics and/or economics education, then surely it would be manifest in the $8^{\text {th }}$ edition published in 2019? Unfortunately, no. No mention is made of pluralism, rethinking economics, or reconceptualizing economics; 3-D printing, Big Data, increased use of the commons, declining marginal cost, the UN 17 Sustainable Development Goals, species depletion, ethics, etc. It is as if these topics did not exist. Students are being taught the same stuff, through the same outdated $19^{\text {th }}$ century lens. They are still being proselytized and not educated. Not only is this bullying, it is an injustice.

This is why the public should be outraged. And in addition, the inability of neoclassical economics to recognize change, and its failure to develop the requisite resources to effectuate it. This is a blind spot of neoclassical economics. And the public suffers.

And from my perch as (founding) editor of a pluralist and interdisciplinary economics journal editor, I see more scholars interested in publishing such papers, but at the same time, a reluctance to do so, given that many promotion committees do not recognize such work; and the omnipotent benchmarking efforts spearheaded by the neoclassical nexus which rewards well-established (mostly neoclassical) journals while largely ignoring newly established and pluralist ones. The well-established nexus pointed out by Fullbrook, forces conformity, while extirpating vitality.

But why should this time be any different? Why should reform succeed now, when it has failed before? This time around, individuals are networked in real time and no longer isolated, which is significant in building and keeping momentum. I believe "we have reached a bifurcation point, a point of no return, a point where we can never return to the dominance of intoleration" (Reardon, 2017a, p. 7). The world is ready for a pluralist, real-world economics. Let's use this opportunity to offer something of value.

\section{Are Ethics and Morals Relevant to Economic Science?}

The use of the word 'science' here is interesting: Rather than label economics as a discipline, or as a social science, or an art, it is labeled here a science. Steve Keen (and many others) have argued that economics is far from a science. That, in fact, it is "a prescience, rather like astronomy before Copernicus, Brahe and Galileo" given "its irrational tenacity with which it holds to its core beliefs in the face of either contrary factual evidence or theoretical critiques" (Keen, 2011, p. 158). Ironically, it was the attempt to emulate $19^{\text {th }}$ century physics and mechanics, that political economy divorced itself from politics and became economics. At the time, however, this was a progressive, ambitious move, and a sincere effort to emulate the progressive sciences: "The Theory of Economy thus treated presents a close analogy to the science of Statical Mechanics, and the Laws of Exchange are found to resemble the Laws of Equilibrium of a lever as determined by the principle of virtual velocities" (Jevons, 1871/1931, p. vii).

Of course, it was expected that their intellectual heirs would further refine and work on the theory, as was ongoing in all of the sciences. But this didn't happen; neoclassical economics became ossified in the $19^{\text {th }}$ century. It is interesting to compare the historical trajectories of physics and neoclassical economics: the former, an empirically-based science, revolutionizing how we view the world, its empirical findings giving us many of the accouterments of modern life; the other a quasi-faith, with its adherents stubbornly clinging to a comfortable $19^{\text {th }}$ century way of thinking.

Pertaining to ethics, a quick (but unscientific) perusal through the index of various (neoclassical) economics textbooks reveals a surprising (and disturbing) lack of discussion on ethics and morals. Perhaps if the newly reconstituted economics defines itself as the 'science' of allocating unlimited wants amongst scarce means, and if it assumed that wants are by nature unlimited, then there is no need for ethics. But if economics is more appropriately defined as the science of provisioning (as do most heterodox economics), then ethics becomes imperative, especially an inter-generational ethics, given the increasing deleterious effects of global warming. 
From my undergraduate philosophy courses, I realized that ethics is subjective and that a universally accepted set of ethics is impossible; and that even an agreed upon definition is elusive. Nevertheless, a healthy discussion of ethics instills respect for others, and can be, and often is, the first step towards pluralism.

According to The Encyclopedia of Philosophy, the term 'ethics' (sometimes called moral philosophy) is used in three different but related ways: "(1) a general pattern or 'way of life'; (2) a set of rules of conduct or 'moral code'; and (3) inquiry about ways of life and rules of conduct" (Abelson \& Nielsen, 1967, p. 81). Hence, it should be no surprise that "

what ethics... is, and at best ought to be, has always been variously conceived by philosophers. There is no uncontroversial Archimedean point from which ethics can be characterized, for the nature and proper office of ethics is itself a hotly disputed philosophical problem. (Abelson \& Nielson, 1967, p. 117)

While we can easily debate the nuts and bolts of ethics without ever coming to an agreement, a rudimentary and workable framework for ethics is: "what to do, what to seek, and how to treat others" (Abelson \& Nielson, 1967, p. 117). This is usually augmented with a necessary concern of the individual for the greater and spiritual whole, however that is defined, since the individual is not alone either in this world or in the economy.

Instead of an ethical framework, neoclassical economics is imbued with the following maxims. Consume as much as possible; maximize individual happiness; maximize GDP, regardless of its negative environmental effects, since they aren't counted anyway. Ignore sustainability and label pollution an externality, and don't consider environmental costs ex ante. Maximize production and forget about any ill effects on future generations. Although an ethicallyconcerned teacher can engage students (Wight, 2012), the overall message is loud and clear: ethics need not matter. Ironically, this is partly due to Adam Smith. Ironic, because a central message of the Theory of Moral Sentiments (Smith, 1759/1761) is that we have to be concerned morally with how we live our lives in the context of an economic system. But in The Wealth of Nations, Smith wrote, by directing that industry in such a manner as its produce may be of the greatest value, he [sic] intends only his own gain, and he is in this, as in many other cases, led by an invisible hand to promote an end which was no part of his intention... By pursuing his own interest he frequently promotes that of the society more effectually than when he really intends to promote it. (Smith, 1776/1976, pp. 477-478)

It is interesting that in the very next sentence Smith writes, "I have never known much good done by those who affected to trade for the public good" ( $\mathrm{p}$. 478). Elinor Ostrom (1990), however, proffers numerous examples of working and trading to protect the commons. And ironically, her work offers more fruitful lessons in the age of sustainability than The Wealth of Nations.

That ethics need not matter in the traditional philosophic sense is also due to the founders of the neoclassical economics eschewing class conflict and distribution issues (a central concern of all the classical economists, including Adam Smith) and embracing a more benign and utilitarian view of capitalism loosely based on utilitarianism. In his preface to The Theory of Political Economy, Jevons wrote,

In this work I have attempted to treat Economy as a Calculus of Pleasure and Pain, and have sketched out, almost irrespective of previous opinions, the form which the science, as it seems to me, must ultimately take... The nature of Wealth and Value is explained by the consideration of indefinitely small amounts of pleasure and pain, just as the Theory of Statics is made to rest upon the equality of indefinitely small amounts of energy. (Jevons, 1871/1931, pp. vivii)

This lack of ethical concern is imbued throughout the neoclassical curriculum. But a reconceptualized economics, however, must be anchored by ethics, as used in the traditional sense. We need a new, ethically-based economics and a new economics education. This is why I wrote my principles of economics textbook (Reardon et al., 2018) emphasizing pluralism, sustainability, and justice (as one form of ethics). A reconceptualized economics must incorporate all three themes; it is impossible to write about one without writing about the others. Pertaining to justice, we wrote, 
The word 'justice' is derived from the Latin Justitia, and like sustainability, is multifaceted and contestable. Essentially, it means fair, equitable, due treatment according to custom and the law. More specifically, we feel that a just society ensures that basic human needs are met, investing in the social well-being of all its members, especially those unable to provide for themselves. (Reardon et al., 2018, p. 19)

While justice is admittedly only one form of ethics, it is appropriate within the context of sustainability, and comports with the three ways ethics has been traditionally used. But what exactly is justice? And how can we implement it? Amartya Sen noted the difficulty in agreeing on what is just and fair, while at the same time, it is easier to recognize and then remedy injustice: "What moves us, reasonably enough, is not the realization that the world falls short of being completely just - which few of us expect - but that there are clearly remediable injustices around us which we want to eliminate" (Sen, 2009, p. vii).

Obvious remediable injustices include an individual not being able to provision for herself, a nation unable to provide a decent life for its citizens, and environmental degradation. Islamic economics offers many fruitful suggestions for constructing a just and sustainable society. The concern for justice and identifying 'clearly remediable injustices', should be the focus of a new economics, which will force economists to speak up on the side of humanity (Robinson, 1981, p. xiii).

Before I leave this topic, I should point out something Alfred Marshall wrote; an ethical obligation that every economist should have toward his/her craft:

It is the duty of those who are giving their chief work to a limited field, to keep up close and constant correspondence with those who are engaged in neighbouring fields. Specialists who never look beyond their own domain are apt to see things out of true proportion; much of the knowledge they get together is of comparatively little use; they work away at the details of old problems which have lost most of their significance and have been supplanted by new questions rising [sic] out of new points of view; and they fail to gain that large illumination which the progress of every science throws by comparison and analogy on those around it. (Marshall, 1890/1946, pp. 770-771)
I can think of no better ethical obligation of an economist towards his/her students, fellow citizens, and government officials.

If the economics profession was populated by such economists, would the most recent crisis have been prevented? Would basic needs be met? If our economic system was based on justice, would it be genuinely focused on sustainability? The answer to all three questions is an unambiguous yes. And our economic system would be very different. As the world changes, as economic conditions change, it is incumbent for the economists to change, along with economics education, so that the discipline of economics can progress forward. This is the quintessence of an ethically-based science.

\section{Is History of Economic Thought Still Relevant? ${ }^{(3)}$}

In his History of Economic Analysis, Schumpeter famously wrote, "So far as our subject is concerned we may safely leap over 500 years to the epoch of $\mathrm{St}$ Thomas Aquinas (1225-74) [from Charlemagne (742-814)]" (Schumpeter, 1954, p. 74). For many of us, receiving bachelor's and doctorate degrees in economics in the west during the 1990s (at least those of us fortunate to take courses in history of economic thought), the history begins with Adam Smith as the founder of economics. Yes, the Scholastics and the Mercantilists were discussed, and even that of the Greeks. But the focus of the course, given this socalled great gap, was almost exclusively western focused.

In an important book, Islahi (2014) documented the extensive writings and contributions to economic theory made by Islamic economists precisely during this great gap. Just about all the topics in today's principles of economics textbooks were first developed by Islamic scholars during the $9^{\text {th }}-11^{\text {th }}$ century; and many arguments made by Smith in The Wealth of Nations were appropriated without due recognition. Islahi wrote that "until at least a chapter is allocated on the Islamic economic thought in textbooks of economics, ignorance and misconception will persist" (2014, p. 99). Thankfully, such a beginning has been made, and although we have a long way to go, this effort clearly demonstrates a palpable benefit of

(3) This section is taken from my module on the History of Economic Thought for the GADE (2019, forthcoming). 
the study of history of thought, and especially Islamic economic thought: It clears up any misconceptions and by doing so, strengthens the bonds between East and West.

In addition to this important rationale, several additional reasons for studying the history of economic thought can be offered. One, Fred Lee reminds us that

the history of economics is not simply an intellectual history, [or just] a history of economic ideas, ... [but] an interwoven, interdependent narrative of ideas and community. Without the [interdependent] history of community, there cannot be a real understanding of how and why the theory developed the way it did. (Lee, 2009, p. 11)

Two, a study of the history of economic thought reveals economics as political. Hence, a theory might have been jettisoned not because it was superseded by a better one, but rather for ideological reasons (Halevi, 2018, p. 33). And of course, a particular theory might be accepted not because it had better intellectual merit, but because it better serves the interest of the dominant class or faction. Thus, economics is not teleological, meaning today's ideas and theories are not necessarily superior to earlier ideas; and conversely, earlier ideas can help shed light on today's problems.

Three, and very much related to the second, is that studying and understanding the history of thought, illustrates how power is used to allocate various modes of thinking and to structure the economy.

Four, who we are today is a function of our past, the roads taken and not taken. Sure, we can take a scientific account of data metrics to learn the specifics, but a full contextual understanding can only occur with an in-depth understanding of one's past. The historian Margaret MacMillan wrote

history is something we all do... we want to make sense of our lives, and often we wonder about our place in our own societies and how we got to be here. So we tell ourselves stories... and we ask questions about ourselves, [which] inevitably lead us to the past. (MacMillan, 2009, p. ix)

And, not surprisingly, for students, it is the "stories, people and debate [that] make economic theory come alive" (Friedman, 2018, p. 78).
Five, understanding past and present can also help us chart a road for the future. Knowing how our discipline came to be, and the obstacles that arose forcing development in one direction or another, can help us understand how we can develop our discipline in order to solve today's pressing problems. It is this nexus of past/present/future that drives the discipline forward, and understanding how we developed into what we are today is a necessary first step. Even though "each historical event is a unique congeries of factors, people or chronology. Yet by examining the past, we can get some useful lessons about how to proceed and some warning about what is or is not likely to happen" (MacMillan, 2009, pp. 153154)

A study of the past not only helps us think about the present, but "aids in formulating questions, and without good questions it is difficult to begin to think in a coherent way at all" (MacMillan, 2009, p. 167).

Six, the study of past economic theory often generates new ways of thinking and new ideas. This happens for two different but interlocking reasons: (1) given that economics isn't teleological, certain ideas that were earlier shunned for political reasons might either be appropriate today or could spark thinking on how best to develop or create; and (2) a thorough understanding of history can elucidate contemporary intellectual bottlenecks.

Seven, it is no coincidence that efforts to reconceptualize economics have also called for a return to the history of economic thought since, "Knowledge of the past helps us to challenge dogmatic statements and sweeping generalisations... it also warns of the dangers of assuming that there is only one possible way of looking at things, or only one course of action" (MacMillan, 2009, p. 165 \& 168). History of economic thought is necessary to understand how different communities exist within the discipline of economics; how they came to espouse different visions, and how they address today's economic problems.

And finally, the study of history will not only be an induction into the discipline but it segues nicely into interdisciplinary (and intra-disciplinary) learning, as students see and engage in the broader debates; where the discipline's boundaries are, and how they have evolved over time (Fuller, 2018, pp. 129, 130, \& 142). 
As is well-known, history of economic thought has been jettisoned from the economics curriculum, usually for the following reason posited by Schumpeter (playing the devil's advocate):

Current work... will preserve whatever is still useful of the work of preceding generations. Concepts, methods, and results that are not so preserved are presumably not worth bothering about. Why then should we go back to old authors and rehearse outmoded views? (Schumpeter, 1954, p. 4).

But as this section has demonstrated, the study of the history of economic thought is necessary to understand how our economy works; and as a muchneeded instrument to help repair, 'relations between East and West'. Any workable and effective history of economics has to be all-inclusive rather than deliberately exclusive, while detailing the theories of all communities in economics, of all its tribes, especially theories jettisoned for political reasons.

Pertaining to the question: Is history of thought relevant in an age of Big Data?; the answer is yes. But not as a linear, horizontal presentation of ideas, but, rather, linked to broader questions that have long interested economists. For example, in my module on the history of economic thought, I discuss contemporary issues that are relevant to students, and then dig deep into the past to elucidate. So, for example, the increased role of the commons is historically linked to capitalism, socialism, and the role of the state; Big Data and the Internet of Things is linked with ethics; universal basic income is linked with the labor theory of values, etc. Only by connecting the present to the past, can we understand our future.

\section{What Implications Does Contemporary Reform Have for Islamic Economics?}

The current reformation of economics presents a golden opportunity for the West to examine the rich repository of Islamic economics, to enable our economies to provision for all and to make them more sustainable. In 2015, the IJPEE published a (double) special issue on the importance of Islamic economics, guest edited by Asad Zaman and myself. In the foreword, we wrote:

In reading these papers we are convinced of the myopic irrelevance of most of neoclassical economics; its deductive, anti-historical modus operandi is not only inefficacious, but the wrong medicine for our times. We need a reconceptualisation of economics, anchored by pluralism and an ethical concern for the less fortunate. Islamic Economics has a lot to offer: Not only does it go beyond the narrow and artificial duality of market v. government, but its clarion call for a just economic system in which surplus wealth is redistributed, its focus on provisioning where the poor are cared for, strongly resonates with heterodox economics. Of course, we do not imply that Islamic economics has all the answers - no view does - only that we need to dialogue, listen and learn from all disciplines within economics (Zaman \& Reardon, 2015, p. 321.)

What follows are several suggestions (or talking points) to effectuate a fruitful collaboration between Western and Islamic economics, and to help restructure our economies so that they can provision for all:

- The concept of holistic development is well developed in Islamic economics; how can this be developed and implemented in the West?

- What is justice? How can it be implemented to help us provision? How can injustice be identified? What are the obstacles to removing injustice?

- In transitioning from our current economic system, which has failed to adequately provision for all, to a new one that does, what obstacles block our way? How can we minutely map these obstacles in order to successfully transition?

- What does 'adequately provision for all' actually mean?

- Can we clearly connect the lessons from Islamic history of economic thought to the problems of today's world? Especially in the West which is gripped by greed and rabid material consumption.

- Neoclassical economics has usurped the important concepts of savings, consumption, investment, and growth. How can we retrofit them to resonate with sustainability and adequate provisioning (like Einstein retrofitted Newton's concepts of mass, acceleration, velocity, etc.)?

- How can economics, economics education, and our economies, be made sustainable and more compatible with fair and adequate provisioning for all? 
- How do rapid advances in technology, along with Big Data and the Internet of Things, affect our ability to adequately provision? How does changing technology affect the meaning of work and labor, and the practicality of implementing a basic income?

\section{Conclusion}

In the novel The Utopia, Thomas More envisioned a happy but mythical society (Utopia) without poverty, money, unemployment, or private property. That Utopia has never existed, does not mean that we should jettison any hope of constructing such a society, in which everyone is adequately provisioned. In Introducing a New Economics, we wrote:

We believe that we can effectively design an economic system so that it provisions for all, not

\section{References}

Abelson, R., \& Nielsen, K. (1967). History of Ethics. In P. Edwards (Ed.), The Encyclopedia of Philosophy (vol. 3/4, pp. 81-117). New York, USA: Macmillan.

Backhouse, R. E., \& Bateman, B. W. (2011, November 5). Wanted: Worldly Philosophers. The New York Times. Retrieved from: https://www.nytimes.com/2011/11/06/opinion/sunday/ worldly-philosophers-wanted.html

Coyle, D. (2007). The Soulful Science: What Economists Really Do and Why it Matters. Princeton, USA: Princeton University Press.

Dow, S. (2009). History of Thought, Methodology and Pluralism. In J. Reardon (Ed.), The Handbook of Pluralist Economics Education (pp. 43-53). London, UK: Routledge.

Dowd, D. F. (2004). Capitalism and its Economics: A Critical History. London, UK: Pluto Press.

Earle, J., Moran, C., \& Ward-Perkins, Z. (2016). The Econocracy: The Perils of Leaving Economics to the Experts. Manchester, UK: University of Manchester Press.

Friedman, G. (2018). Introducing Institutional Microeconomics through the Study of the History of Economic Thought. In D. Tavasci \& L. Ventimiglia (Eds.), Teaching the History of Economic Thought: Integrating Historical Perspectives into Modern Economics (pp. 75-90). Cheltenham, UK: Edward Elgar.

Fullbrook, E. (Ed.). (2004). A Guide to What's Wrong with Economics. London, UK: Anthem Press. just for today but also for tomorrow. This is the essence of sustainability [and justice], and this is the obligation of the educated - a quid pro quo to help make the world a better place (Reardon et al., 2018, p. 225).

Reconceptualizing economics takes time. It is like putting the pieces of a puzzle together (although the puzzle analogy only goes so far, since the economy itself is changing). No one piece is preponderant and each piece relates to the greater whole. But this is our economy, not the politician's or the econocracy's. If it no longer works, if it no longer provisions for all, we must change it. Pluralism is a necessary start but it is not sufficient: we need an active engagement by all to reconceptualize a new economics.

Fullbrook, E. (2009). The Meltdown and Economics Textbooks. In J. Reardon (Ed.), The Handbook of Pluralist Economics Education (pp. 17-23). London, UK: Routledge.

Fullbrook, E. (2010). How to bring economics into the 3rd millennium by 2020. Real-World Economics Review, 54, 89-102.

Fuller, S. (2018). Teaching and Learning with Historical Perspectives. In D. Tavasci \& L. Ventimiglia (Eds.), Teaching the History of Economic Thought: Integrating Historical Perspectives into Modern Economics (pp. 129-144). Cheltenham, UK: Edward Elgar.

George, H. (1935). Progress and Poverty: An Inquiry into the Cause of Industrial Depressions, and of Increase of Want with Increase of Wealth - The Remedy. New York, USA: Robert Schalkenbach Foundation. (Original work published 1879)

Halevi, J. (2018). Teaching Economic Theory based on the History of Economic Thought. In D. Tavasci \& L. Ventimiglia (Eds.), Teaching the History of Economic Thought: Integrating Historical Perspectives into Modern Economics (pp. 32-48). Cheltenham, UK: Edward Elgar.

Heise, A. (2017). Defining economic pluralism: ethical norm or scientific imperative. International Journal of Pluralism and Economics Education, 8(1), 18-41.

Islahi, A. A. (2014). History of Islamic Economic Thought: Contributions of Muslim Scholars to Economic Thought and Analysis. Cheltenham, UK: Edward Elgar. 
Jevons, W. S. (1931). The Theory of Political Economy. London, UK: Macmillan and Co. (Original work published 1871)

Keen, S. (2011). Debunking Economics: The Naked Emperor Dethroned. London, UK: Zed Books.

Kuhn, T. (2012). The Structure of Scientific Revolutions. Chicago, USA: The University of Chicago. (Original work published 1962)

Lee, F. (2009). A History of Heterodox Economics: Challenging the Mainstream in the Twentieth Century. London, UK: Routledge.

MacMillan, M. (2009). Dangerous Games: The Uses and Abuses of History. New York: Random House.

Mankiw, N. G. (2007). Principles of Economics (4th ed.). Mason, Ohio, USA: Cengage Learning.

Mankiw, N. G. (2009, May 23). That Freshman Course Won't Be Quite the Same. The New York Times. Retrieved from: https://www.nytimes.com/2009/05/24/business/econo my/24view.html

Marshall, A. (1946). Principles of Economics. London, UK: MacMillan. (Original work published 1890)

Marx, K., \& Engels, F. (1992). The Communist Manifesto. Oxford, UK: Oxford University Press. (Original work published 1848)

More, T. (1895). The Utopia (J. H. Lupton, Trans.). Oxford, UK: Clarendon Press. (Original work published 1516)

Negru, I. (2009). Reflections on Pluralism in Economics. International Journal of Pluralism and Economics Education, 1(1/2), 7-21.

Negru, I. (2010). Plurality to Pluralism in Economics Pedagogy: The Role of Critical Thinking. International Journal of Pluralism and Economics Education, 1(3), 185-193.

Negru, I., \& Negru, A. (2017). Modes of pluralism: Critical Commentary on the Roundtable Dialogue on Pluralism. International Journal of Pluralism and Economics Education, 8(2), 193-209.

Ostrom, E. (1990). Governing the Commons: The Evolution of Institutions for Collective Action. Cambridge, UK: Cambridge University Press.

Otsch, W., \& Kapeller, J. (2010). Perpetuating the Failure: Economic Education and the Current Crisis. Journal of Social Science Education, 9(2), 16-25.

Post-Autistic Economics Network. (2000). Open Letter from Economics Students to Professors and Others Responsible for the Teaching of This Discipline. Retrieved from: http://www.paecon.net/petitions/a-epetition.htm
Reardon, J. (Ed.). (2009). The Handbook of Pluralist Economics Education. London, UK: Routledge.

Reardon, J. (2015). Roundtable dialogue on pluralism. International Journal of Pluralism and Economics Education, 6(3), 272-308.

Reardon, J. (2017a). Editorial: When will economics become pluralist? International Journal of Pluralism and Economics Education, 8(1), 7-13.

Reardon, J. (2017b). Foreword: Why economics needs its own reformation - 95 theses. International Journal of Pluralism and Economics Education, 8(4), 319-329.

Reardon, J., Madi, M. A. C., \& Cato, M. S. (2018). Introducing a New Economics: Pluralist, Sustainable and Progressive. London, UK: Pluto Press.

Rethinking Economics. (2014, April 4). Manifesto: A direction for the reform of economics education. Retrieved from: http://rethinkingeconomics.blogspot.com/2014/04/draft -manifesto-direction-for-reform-of.html

Robinson, J. (1981). What are the Questions and Other Essays. New York, USA: M.E. Sharpe.

Schumacher, E. F. (1989) Small is Beautiful: Economics as if People Mattered. New York: Harper Perennial. (Original work published 1973)

Schumpeter, J. (1954). The History of Economic Analysis. New York: Oxford University Press.

Sen, A. (2009). The Idea of Justice. London, UK: Penguin.

Smith, A. (1761). The Theory of Moral Sentiments. London, UK: A. Millar, A. Kincaid and J. Bell. (Original work published 1759)

Smith, A. (1976). An Inquiry into the Nature and Causes of the Wealth of Nations. Chicago, USA: The University of Chicago Press. (Original work published 1776)

Snow, C. P. (1988). The Two Cultures. Cambridge, UK: Cambridge University Press.

Weehuizen, R. (2007). Interdisciplinarity and Problembased Learning in Economics Education: The Case of Infonomics. In J. Groenewegen (Ed.), Teaching Pluralism in Economics (pp. 155-188). Cheltenham, UK: Edward Elgar.

Wight, J. B. (2012). Ethics and Critical Thinking. In G. M. Hoyt \& KM. McGoldrick (Eds.), International Handbook on Teaching and Learning Economics (pp. 197204). Cheltenham, UK: Edward Elgar.

Zaman, A., \& Reardon, J. (2015). Foreword. International Journal of Pluralism and Economics Education, 6(4), 313-323. 
Jack Reardon is the founding editor of the International Journal of Pluralism and Economics Education. He teaches economics at the University of Wisconsin-Eau Claire. His research interests include economics education, energy and the environment, and labor economics. He has published in a wide variety of journals including the Journal of Economic Issues, Monthly Labor Review, and International Journal of Green Economics. He has published many books including: A Handbook for Pluralist Economics Education (Routledge); The Economics Curriculum: Towards a Radical Reformulation (World Economics Association Books); and the economics textbook, Introducing a New Economics (Pluto Press).

E-mail: jackreardon864@gmail.com; reardonj@uwec.edu 


\title{
حوارحول الإصلاح في الاقتصياد السائد و انعكاسـه على الاقتصياد الإسلامي
}

\author{
جاك ريردون \\ المحرر المؤسس للمججلة الدولية لتعليم التعلددية والاقتصياد \\ أستاذ، جامعة وليسكونسن - أوكلير، الولايات المتحسلة الأمريكية
}

المستخلص: أبرزت الأزمة المالية العالمية الأخيرة عدداً من التشوهات في الاقتصهاد السائد، لذلك كانت

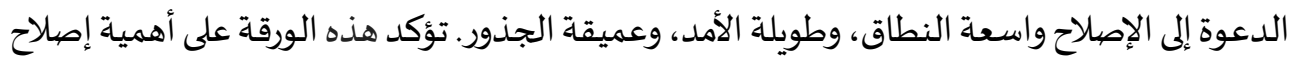
الاقتصاد من المنظور التاريخي، -حيث كان الاقتصاد في الماضي يتميز بقدر أكبر من التعددية العلمية -

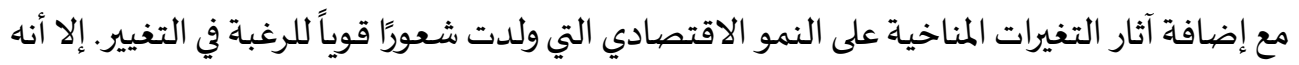

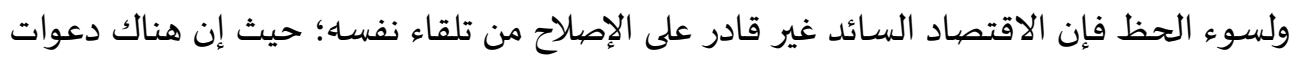

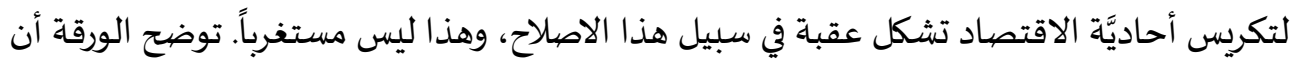
هناك بعض الإصلاحات الجوهرية البسيطة التي حدثت في الاقتصاد السائد، استجابة للدعوات المستمرة والملحة للإصلاح. كما تدعو الورقة إلى تعددية النظريات الاقتصادية باعتبارها أساسًا فكريًا

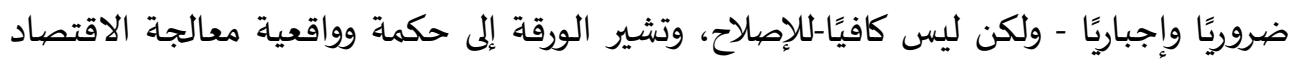
الإسلامي لكثير من المشكلات الاقتصادية السائدة. الكلمات الدَّالة: التعددية ، تعليم الاقتصاد ، إصلاح الاقتصياد.

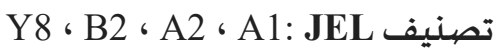
تصنيف G63، G6، G1، G0: KAUJIE 